\section{Survey of Brazilian governmental health agencies shows conflicting recommendations concerning oral hygiene practices for children}

\author{
Pesquisa com Secretarias de Saúde no Brasil revela \\ recomendações divergentes relacionadas a práticas \\ de higiene bucal em crianças
}

\author{
1 Instituto de Medicina \\ Social, Universidade do \\ Estado do Rio de Janeiro, Rio \\ de Janeiro, Brasil. \\ 2 Faculdade de Odontologia, \\ Universidade do Estado do \\ Rio de Janeiro, Rio de Janeiro, \\ Brasil. \\ Correspondência \\ A. P. P. Santos \\ Instituto de Medicina Social, \\ Universidade do Estado do Rio \\ de Janeiro. \\ Rua São Francisco Xavier 524, \\ 7 o andar, Rio de Janeiro, $R J$ \\ 20559-900, Brasil. \\ ana.paulapires@uol.com.br
}

\begin{abstract}
The aims of this study were to detect whether recommendations concerning oral hygiene practices for children among Brazilian health agencies are consistent and to verify whether possible inconsistencies in these recommendations might be associated with an apparent gap in the scientific evidence. Fifty-four Brazilian health agencies were contacted by mail or electronic mail and were asked to send any material containing recommendations on oral hygiene practices aimed at children. A search was subsequently carried out on the Cochrane Oral Health Review Group and PubMed-Clinical Queries websites in order to assess the scientific evidence available on this subject. Forty (74\%) agencies answered and 21 materials containing oral hygiene recommendations were obtained. Eleven pertinent systematic reviews were identified. This preliminary study detected some conflicting and not evidence-based oral hygiene messages, which emphasizes the need to carry out and disseminate systematic reviews on these controversial issues in order to bridge the gap between knowledge and practice.
\end{abstract}

Oral Hygiene; Dental Care for Children; EvidenceBased Dentistry
Ana Paula Pires dos Santos 1

Paulo Nadanovsky 1

Branca Heloisa de Oliveira ${ }^{2}$

\section{Introduction}

Health messages targeted at populations should be clear, consistent and based on the most reliable evidence currently available as polices based on flawed evidence may adversely affect public health. Often, conflicting health messages are a consequence of difficulties in closing the "knowledge-to-practice gap": knowledge is available, but healthcare professionals do not assess or apply it. At other times, conflicting health messages are the consequence of a lack of or poor scientific evidence, or still, evidence may be available but has not been systematically summarized 1 .

This preliminary study had two aims: (1) to detect whether recommendations on oral hygiene practices for children among Brazilian health agencies are consistent and (2) to verify whether possible inconsistencies in these recommendations might be associated with an apparent gap in the scientific evidence.

\section{Methods}

The following Brazilian governmental health agencies were contacted by electronic mail and/or mail: the National Oral Health Agency/ Ministry of Health (CNSB), the 26 State Health Agencies, the 26 Municipal Health Agencies of Brazilian capitals and the State Health Agency of the Brazilian Federal District. A first round of 
emails was sent to each agency in September 2008. Where no answer was forthcoming, four more attempts (two emails and two letters) were made up until April 2009. The emails and postal addresses were obtained either through Google or by making direct contact with the CNSB. The agencies were requested to send any and all educational materials such as brochures, leaflets or folders containing recommendations regarding children's oral hygiene practices aimed at the general public. They were also asked whether recommendations on this topic were disclosed on their websites.

The scientific evidence was obtained from systematic reviews available at the Cochrane Oral Health Review Group (http: / / www.ohg.cochrane. org/reviews.html, accessed on 19/Jul/2009) and at PubMed Clinical Queries, using the filter "Find Systematic Reviews" and the text words "oral hygiene" and "dentifrices" (http://www.ncbi.nlm. nih.gov/corehtml/query/static/clinical.shtml, accessed on 19/Jul/2009). The search and selection of the systematic reviews were performed by one author (A.P.P.S.). Whenever there were any doubts about the pertinence of a review, another author (P.N.) was consulted and any disagreement was resolved by consensus.

\section{Results}

Forty of the 54 (74\%) governmental health agencies answered; 19 reported not producing the material requested, while 21 sent some kind of material, either in print or electronic format (Table 1). All the materials mentioned children's oral hygiene practices such as toothbrushing frequency, toothbrushing supervision, when to start and how long toothbrushing should last, toothbrush design and replacement, flossing, gums/ teeth wiping, tongue cleaning, type and amount of toothpaste and advice on toothpaste ingestion (Table 2).

The search carried out at the Cochrane Oral Health Review Group website resulted in 91 systematic reviews, among which 5 were considered pertinent to the present study. The search carried out at the PubMed Clinical Queries website yielded 249 citations using the text word "oral hygiene" and 71 using the text word "dentifrices", and a further 6 pertinent systematic reviews were identified. Only systematic reviews focusing on oral hygiene practices aimed at children were considered (Table 3).

\section{Discussion}

Gathering and disseminating reliable knowledge from systematic reviews plays a key role in evidence-based practice. However, systematic reviews yield not only evidence for or against a specific intervention, but also the lack of scientific support for some current practices. Among the 11 systematic reviews included in this study, 8 highlighted the need for better quality studies to assess issues pertaining to adverse effects and the applicability of the results to different settings 2,3,4,5,6,7,8,9. Moreover, one review was unable to answer the core question due to insufficient evidence 8 .

All Brazilian health agencies that replied to our request provided information on frequency of toothbrushing and the majority of them emphasized the need for toothbrushing before sleeping. However, recommendations on frequency of toothbrushing ranged from at least once a day to after every meal, feeding, sugar or medication intake. Toothbrushing supervision was recommended for children up to 6 to 10 years of age or as soon as they develop the necessary skills. Three systematic reviews assessing the effects of fluoride toothpastes on caries incidence reported that their anti-caries potential is enhanced by daily or twice-daily supervised toothbrushing 3,6,10. However, these conclusions have been drawn from studies that took place in schools or institutions and therefore it has yet to be established whether home supervised toothbrushing with an increased frequency would lead to similar results. Such a gap in the evidence may partly explain the conflicting messages conveyed.

Most materials did not disclose information on when toothbrushing should begin, how long it should last or how often toothbrushes should be replaced. There was agreement in regard to the use of soft-bristled toothbrushes, even though no evidence on this topic has been identified.

A systematic review of the effects of flossing on interproximal caries revealed that professional flossing during school days in children with poor oral hygiene habits and minimal exposure to fluoride is beneficial. On the other hand, no evidence of the effectiveness of self-flossing in the presence of topical fluoride was found. The authors pointed out that some of the trials included in this review were of poor quality and thus further studies assessing simultaneously the effects of fluoride toothpastes and flossing devices should be carried out to establish whether flossing can contribute to reducing interproximal caries when topical fluoride is available ${ }^{9}$. Despite this lack of evidence, 17 out of 21 health agencies suggested that children should have their teeth flossed. 
Materials on children's oral hygiene practices provided by 21 Brazilian governmental agencies.

\begin{tabular}{|c|c|}
\hline Governmental agency & Material provided \\
\hline Ministry of Health & $\begin{array}{l}\text { Brochure/folder sent by email/mail (Caderneta de Saúde da Criança and Mantenha Seu Sorriso Fazendo } \\
\qquad \text { a Higiene Bucal Corretamente) }\end{array}$ \\
\hline SHA Amazonas & Oral health information available at the website (http://www.saude.am.gov.br/index.php?id=bucal) \\
\hline SHA Maranhão & $\begin{array}{l}\text { Folders sent by mail (Saúde Bucal: Um Direito de Todos, Inter-Relação Odontologia/Pediatria and Saúde } \\
\qquad \text { da Boca e dos Dentes) }\end{array}$ \\
\hline SHA Mato Grosso do Sul & Brochure sent by mail (Saúde Bucal em Todas as ldades) \\
\hline SHA Paraná & Folder sent by mail (Dicas Para Você Manter a Sua Saúde Bucal) \\
\hline SHA Piauí & Folder sent by email (Saúde Bucal - A Caminho da Universalização) \\
\hline SHA Rio de Janeiro & Oral health information available at the website (http://www.saude.rj.gov.br/guia_sus_cidadao/pg_32.shtml) \\
\hline SHA Rio Grande do Sul & Folders sent by email (Viva Melhor com Saúde Bucal and Saúde Bucal na Primeira Infância) \\
\hline SHA São Paulo & $\begin{array}{l}\text { Folders sent by email (Sorria Toda Vida, Auto-Exame e Autocuidados em Saúde Bucal and Turma da Mônica } \\
\text { e a Saúde Bucal) }\end{array}$ \\
\hline MHA Aracaju & Folders sent by mail (O Sorriso Saudável ao Alcance de Todos and Dicas para um Sorriso Saudável) \\
\hline MHA Belém & Oral hygiene recommendations sent by email \\
\hline MHA Belo Horizonte & Poster sent by email (15 Maneiras de Cuidar da Saúde Bucal do Bebê, Criança e do Adolescente) \\
\hline MHA Campo Grande & Folders sent by mail (Prevenção em Odontologia para Bebês) \\
\hline MHA Cuiabá & Folders sent by mail (Geração Cárie Zero and A Cidadania Conquistada pelo Sorriso) \\
\hline MHA Florianópolis & Folder sent by mail (Cuide do seu Sorriso e da sua Saúde: Previna a Cárie e a Doença Periodontal) \\
\hline MHA Goiânia & Oral hygiene recommendations sent by email \\
\hline MHA Manaus & Folder sent by email (Programa de Saúde Bucal) \\
\hline MHA Natal & Folder sent by mail (A Saúde Bucal no Boca a Boca) \\
\hline MHA Porto Velho & Oral hygiene recommendations sent by email \\
\hline MHA Rio Branco & Folders sent by mail (Saúde Bucal, Cuide Bem do seu Sorriso and Saiba Mais sobre Creme Dental) \\
\hline MHA Salvador & Oral hygiene recommendations sent by email \\
\hline
\end{tabular}

MHA: Municipal Health Agency; SHA: State Health Agency.

Most materials emphasized the need for gums/teeth wiping. Some of them advised gums wiping before tooth eruption, others advised that wiping should last until the eruption of posterior teeth. Almost half of the materials also suggested that children should have their tongue cleaned. It is not clear whether these practices are recommended in order to prevent dental caries, halitosis or if it is believed that they are part of a comprehensive oral hygiene program that should be established early in children's lives, but neither are evidence-based practices.

Despite the scientific debate about optimal fluoride concentration in toothpastes aimed at children, only 8 agencies provided information on this issue. Some supported the use of nonfluoride toothpastes until the age of 3 or 4, possibly due to dental fluorosis concerns, although it has not yet been assessed to what extent dental fluorosis is attributable to fluoride toothpastes 3 . Additionally, there is a substantial body of evidence emphasizing the anti-caries effect of fluo- ride toothpastes containing either sodium fluoride or sodium monofluorophosphate, as long as they are formulated with compatible abrasive systems 3,6,10,11. Thus, the recommendation of non-fluoride toothpastes lacks scientific support and may have a detrimental effect on children's oral health. Other agencies advocated the use of standard fluoride toothpaste as soon as the first primary tooth breaks through and none of them mentioned the use of low fluoride toothpastes. Two systematic reviews comparing the effects of low versus standard fluoride toothpastes on caries prevention yielded conflicting results 7,8 . One review stated that $250 \mathrm{ppm}$ and $1,000 \mathrm{ppm}$ fluoride toothpastes achieved similar results, whereas the other reported that 250ppm fluoride toothpastes were not as effective as $1,000 \mathrm{ppm}$ ones. Moreover, the latter stated that it was not possible to draw any conclusion regarding 500ppm fluoride toothpastes. As for higher concentrations, it was shown that high-fluoride toothpastes provided lower caries increments in 
Table 2

Oral hygiene recommendations aimed at children provided by 21 Brazilian governmental agencies.

\begin{tabular}{|c|c|c|}
\hline Subject & Recommendation & Number of agencies \\
\hline \multicolumn{3}{|l|}{ Toothbrushing } \\
\hline \multirow[t]{9}{*}{ Toothbrushing frequency * } & Daily & 1 \\
\hline & At least once a day & 1 \\
\hline & 3 times a day & 6 \\
\hline & After meals & 15 \\
\hline & After sugar intake & 2 \\
\hline & After medication intake & 2 \\
\hline & After breast/bottle feeding & 7 \\
\hline & Before sleeping & 15 \\
\hline & Subject not mentioned & - \\
\hline \multirow[t]{11}{*}{ Toothbrushing supervision * } & Toothbrushing should be supervised & 2 \\
\hline & Until 6 years of age & 1 \\
\hline & Until 7 years of age & 4 \\
\hline & Until 9 years of age & 2 \\
\hline & Until 10 years of age & 1 \\
\hline & Until the child is skilled & 2 \\
\hline & From 3 to 7, parents should finish off children's toothbrushing & 1 \\
\hline & Children brush on their own and parents finish off toothbrushing & 2 \\
\hline & Parents should brush their children's teeth until 7 years of age & 1 \\
\hline & Parents should brush their teeth in front of their children & 4 \\
\hline & Subject not mentioned & 8 \\
\hline \multirow[t]{4}{*}{ When to start toothbrushing } & When the first primary tooth emerges & 5 \\
\hline & When the first primary molar emerges & 2 \\
\hline & At 18 months of age & 1 \\
\hline & Subject not mentioned & 13 \\
\hline \multirow[t]{3}{*}{ Time spent at toothbrushing } & 5-8 minutes & 1 \\
\hline & 10 seconds per 2 teeth & 1 \\
\hline & Subject not mentioned & 19 \\
\hline \multirow[t]{7}{*}{ Toothbrush design * } & Finger toothbrush (for babies) & 1 \\
\hline & Small head & 9 \\
\hline & Soft bristles & 15 \\
\hline & Vertical bristles & 2 \\
\hline & End-rounded bristles & 2 \\
\hline & Straight handle & 2 \\
\hline & Subject not mentioned & 6 \\
\hline \multirow[t]{6}{*}{ Toothbrush replacement * } & Every 2-3 months & 1 \\
\hline & Every 3 months & 2 \\
\hline & Every 3-4 months & 1 \\
\hline & When it becomes worn out & 6 \\
\hline & Whenever children catch a cold or flu & 1 \\
\hline & Subject not mentioned & 15 \\
\hline \multirow[t]{3}{*}{ Flossing } & Children should have their teeth flossed & 4 \\
\hline & Daily & 13 \\
\hline & Subject not mentioned & 4 \\
\hline \multirow[t]{4}{*}{ Gums/Teeth wiping } & Until the first primary tooth emerges & 8 \\
\hline & Until the first primary molar emerges & 4 \\
\hline & Until one year and a half & 1 \\
\hline & Subject not mentioned & 8 \\
\hline
\end{tabular}

(continues) 


\begin{tabular}{|c|c|c|}
\hline Subject & Recommendation & Number of agencies \\
\hline \multirow[t]{2}{*}{ Tongue cleaning } & Children should have their tongue cleaned & 10 \\
\hline & Subject not mentioned & 11 \\
\hline \multicolumn{3}{|l|}{ Toothpaste } \\
\hline \multirow[t]{5}{*}{ Type of toothpaste * } & Non-fluoride toothpaste until 3 years of age & 1 \\
\hline & Non-fluoride toothpaste until 4 years of age & 1 \\
\hline & Fluoride toothpaste, irrespective of age & 6 \\
\hline & Toothpaste without abrasives & 2 \\
\hline & Subject not mentioned & 13 \\
\hline \multirow[t]{8}{*}{ Amount of toothpaste * } & Small amount & 5 \\
\hline & $1 / 4$ pea grain & 1 \\
\hline & Pea grain & 1 \\
\hline & Lentil grain & 1 \\
\hline & Bean grain & 1 \\
\hline & Corn grain & 2 \\
\hline & Rice grain & 6 \\
\hline & Subject not mentioned & 8 \\
\hline Advice on toothpaste & Children should not swallow the toothpaste & 6 \\
\hline \multirow[t]{3}{*}{ ingestion } & Children should have their mouth wiped after toothbrushing & 1 \\
\hline & The tube of toothpaste should be kept out of children's reach & 1 \\
\hline & Subject not mentioned & 13 \\
\hline
\end{tabular}

* The number of agencies does not add up to 21 as the same agency may provide more than one recommendation.

the permanent dentition than standard fluoride toothpastes 12 .

Different amounts of toothpaste were recommended. However, apparently all materials supported the use of a small amount. No evidence regarding whether smaller amounts of toothpaste may affect fluoride efficacy was identified.

A thorough assessment of the current evidence was beyond the scope of this preliminary study and the educational materials evaluated may not completely reflect each agency's view concerning oral hygiene practices for children.
In spite of that, this study showed several conflicting and non evidence-based oral hygiene messages. Thus, there is a need to carry out and disseminate systematic reviews on these controversial issues in order to bridge the gap between scientific knowledge and health agencies' recommendations. This will better support public health educational efforts and may help improve oral health practice. 
Table 3

Summary of systematic reviews focusing on oral hygiene practices aimed at children.

\begin{tabular}{|c|c|c|}
\hline Author & Year & Conclusions/Recommendations \\
\hline Marinho et al. 2 & 2003 & $\begin{array}{l}\text { The benefits of topical fluorides have been firmly established. No conclusions about adverse effects } \\
\qquad \text { could be reached }\end{array}$ \\
\hline Marinho et al. 3 & 2003 & $\begin{array}{l}\text { There is clear evidence that fluoride toothpastes are effective in preventing caries, regardless of water fluoridation. } \\
\text { Higher effects were shown with higher baseline caries levels, increased fluoride concentration, increased frequency } \\
\text { of use (twice vs. once/day) and supervised toothbrushing. No conclusions about adverse effects could be reached }\end{array}$ \\
\hline Marinho et al. 4 & 2004 & $\begin{array}{l}\text { Fluoride toothpastes, mouthrinses and gels reduce caries in children and adolescents to a similar extent but } \\
\text { acceptance is likely to be greater for fluoride toothpaste. There is no strong evidence that varnishes are more } \\
\text { effective than other types of topical fluoride. No conclusions about adverse effects could be reached }\end{array}$ \\
\hline Marinho et al. 5 & 2004 & $\begin{array}{l}\text { Topical fluorides (mouthrinses, gels or varnishes) used in addition to fluoride toothpaste achieve a modest reduction } \\
\text { in caries compared to toothpaste used alone. However, combined use of topical fluorides and toothpaste may be } \\
\text { considered for children at higher risk of caries. No conclusions about adverse effects could be reached }\end{array}$ \\
\hline Twetman et al. 6 & 2003 & $\begin{array}{l}\text { There is strong evidence for the effect on caries prevention of daily use of fluoride toothpaste. Superior preventive } \\
\text { effects were found with 1,500ppm F toothpastes and supervised toothbrushing. There is incomplete evidence } \\
\text { regarding the effect of fluoride toothpaste in the primary dentition }\end{array}$ \\
\hline Chaves et al. 10 & 2002 & $\begin{array}{l}\text { Toothbrushing with fluoride toothpaste significantly decreases the incidence of dental caries. Higher caries } \\
\text { reductions were observed when toothbrushing was supervised }\end{array}$ \\
\hline Bartizek et al. 12 & 2001 & $\begin{array}{c}\text { The use of a 2,800ppm F dentifrice showed significantly lower caries increments than the use of a 1,100ppm F } \\
\text { dentifrice in school children. The 1,700ppm F and 2,200ppm F dentifrices showed some directional advantages over } \\
\text { the 1,100ppm F dentifrice, though not statistically significant }\end{array}$ \\
\hline Steiner et al. 7 & 2004 & $\begin{array}{l}\text { Slightly lower caries increments were found in children using } 1,000 \mathrm{ppm} \text { fluoride toothpastes when compared to } \\
\text { children using } 250 \mathrm{ppm} \text { fluoride toothpastes. The authors state that the } 1,000 \mathrm{ppm} \text { toothpaste's effects on fluorosis } \\
\text { and the availability of fluoridated salt justify the use of } 250 \mathrm{ppm} \text { toothpastes for Swiss preschool children }\end{array}$ \\
\hline Ammari et al. 8 & 2003 & $\begin{array}{c}\text { Toothpastes containing 250ppm F were not as effective in caries prevention in permanent dentition as those } \\
\text { containing 1,000ppm F. Data comparing 500ppm with 1,000ppm fluoride toothpastes were very limited and further } \\
\text { research is required }\end{array}$ \\
\hline Proskin et al. 11 & 1995 & $\begin{array}{l}\text { Dentifrices containing fluoride as sodium fluoride or as sodium monofluorophosphate provide equivalent anticaries } \\
\text { effectiveness }\end{array}$ \\
\hline Hujoel et al. 9 & 2006 & $\begin{array}{l}\text { Professional flossing in children with low fluoride exposure and poor toothbrushing habits is effective in reducing } \\
\text { interproximal caries risk. Self-flossing has failed to show an effect. Studies assessing the effects of fluoride } \\
\text { toothpastes and flossing devices are required }\end{array}$ \\
\hline
\end{tabular}

Source: Cochrane Oral Health Review Group (http://www.ohg.cochrane.org/reviews.html) and PubMed - Clinical Queries

(http://www.ncbi.nlm.nih.gov/corehtml/query/static/clinical.shtml). Accessed on 19/Jul/2009.

\section{Resumo}

Os objetivos deste estudo foram verificar se as recomendações fornecidas por órgãos governamentais brasileiros sobre higiene bucal em crianças são consistentes e se possíveis inconsistências nessas recomendações estão associadas a uma aparente falta de evidência científica. Cinqüenta e quatro órgãos governamentais brasileiros foram contatados por endereço eletrônico ou postal. Foi solicitado que enviassem materiais contendo recomendações sobre práticas de higiene bucal para crianças. Em seguida, realizou-se uma busca nos sites Cochrane Oral Health Review Group e PubMed-Clinical Queries para avaliar a evidência científica disponível sobre o assunto. Quarenta (74\%) órgãos governamentais responderam e 21 materiais contendo recomendações sobre higiene bucal foram obtidos. Foram identificadas 11 revisões sistemáticas pertinentes. Este estudo preliminar detectou algumas recomendações divergentes e não baseadas em evidência científica, ressaltando a necessidade de se realizar revisões sistemáticas da literatura sobre esses tópicos para aproximar a pesquisa científica da prática clínica.

Higiene Bucal; Assistência Odontológica para Crianças; Odontologia Baseada em Evidências 


\section{Contributors}

A. P. P. Santos collected the materials provided by the health councils. All three authors contributed to the study concept, design, interpretation, drafting and final editing of the manuscript.

\section{Acknowledgments}

The authors wish to thank all health agencies for providing the materials assessed in this study. A. P. P. Santos received a PhD scholarship from FAPERJ (Rio de Janeiro State Research Foundation). P. Nadanovsky received financial support from CNPq (National Research Council - grant no. 305714/2006-6). B. H. Oliveira received financial support from FAPERJ (E-26/102.248/2009).

\section{References}

1. Straus SE, Richardson WS, Glasziou P, Haynes RB. Evidence based medicine. 3rd Ed. Edinburgh: Churchill Livingstone; 2005.

2. Marinho VCC, Higgins JPT, Logan S, Sheiham A. Topical fluoride (toothpastes, mouthrinses, gels or varnishes) for preventing dental caries in children and adolescents. Cochrane Database of Systematic Reviews 2003; Issue 4. Art. No.: CD002782.

3. Marinho VCC, Higgins JPT, Logan S, Sheiham A. Fluoride toothpastes for preventing dental caries in children and adolescents. Cochrane Database of Systematic Reviews 2003; Issue 1. Art. No.: CD002278.

4. Marinho VCC, Higgins JPT, Sheiham A, Logan S. One topical fluoride (toothpastes, or mouthrinses, or gels, or varnishes) versus another for preventing dental caries in children and adolescents. Cochrane Database of Systematic Reviews 2004; Issue 1. Art. No.: CD002780.

5. Marinho VCC, Higgins JPT, Sheiham A, Logan S. Combinations of topical fluoride (toothpastes, mouthrinses, gels, varnishes) versus single topical fluoride for preventing dental caries in children and adolescents. Cochrane Database of Systematic Reviews 2004; Issue 1. Art. No.: CD002781.

6. Twetman S, Axelsson S, Dahlgren H, Holm AK Källestål C, Lagerlöf F, et al. Caries-preventive effect of fluoride toothpaste: a systematic review. Acta Odontol Scand 2003; 61:347-55.
7. Steiner M, Helfenstein U, Menghini G. Effect of $1000 \mathrm{ppm}$ relative to $250 \mathrm{ppm}$ fluoride toothpaste: a meta-analysis. Am J Dent 2004; 17:85-8.

8. Ammari AB, Bloch-Zupan A, Ashley PF. Systematic review of studies comparing the anti-caries efficacy of children's toothpaste containing 600ppm of fluoride or less with high fluoride toothpastes of 1,000ppm or above. Caries Res 2003; 37:85-92.

9. Hujoel PP, Cunha-Cruz J, Banting DW, Loesche WJ. Dental flossing and interproximal caries: a systematic review. J Dent Res 2006; 85:298-305.

10. Chaves SC, Vieira-da-Silva LM. Anticaries effectiveness of fluoride toothpaste: a meta-analysis. Rev Saúde Pública 2002; 36:598-606.

11. Proskin HM, Volpe AR. Comparison of the anticaries efficacy of dentifrices containing fluoride as sodium fluoride or sodium monofluorophosphate. Am J Dent 1995; 8:51-8.

12. Bartizek RD, Gerlach RW, Faller RV, Jacobs SA, Bollmer BW, Biesbrock AR. Reduction in dental caries with four concentrations of sodium fluoride in a dentifrice: a meta-analysis evaluation. J Clin Dent 2001; 12:57-62.

Submitted on 15/Sep/2009

Final version resubmitted on 21/Apr/2010

Approved on 03/May/2010 